Rice University's Baker Institute

LATIN AMERICA INITIATIVE

RICE UNIVERSITY'S 20 YEARS

BAKER INSTITUTE 2O1993-2013

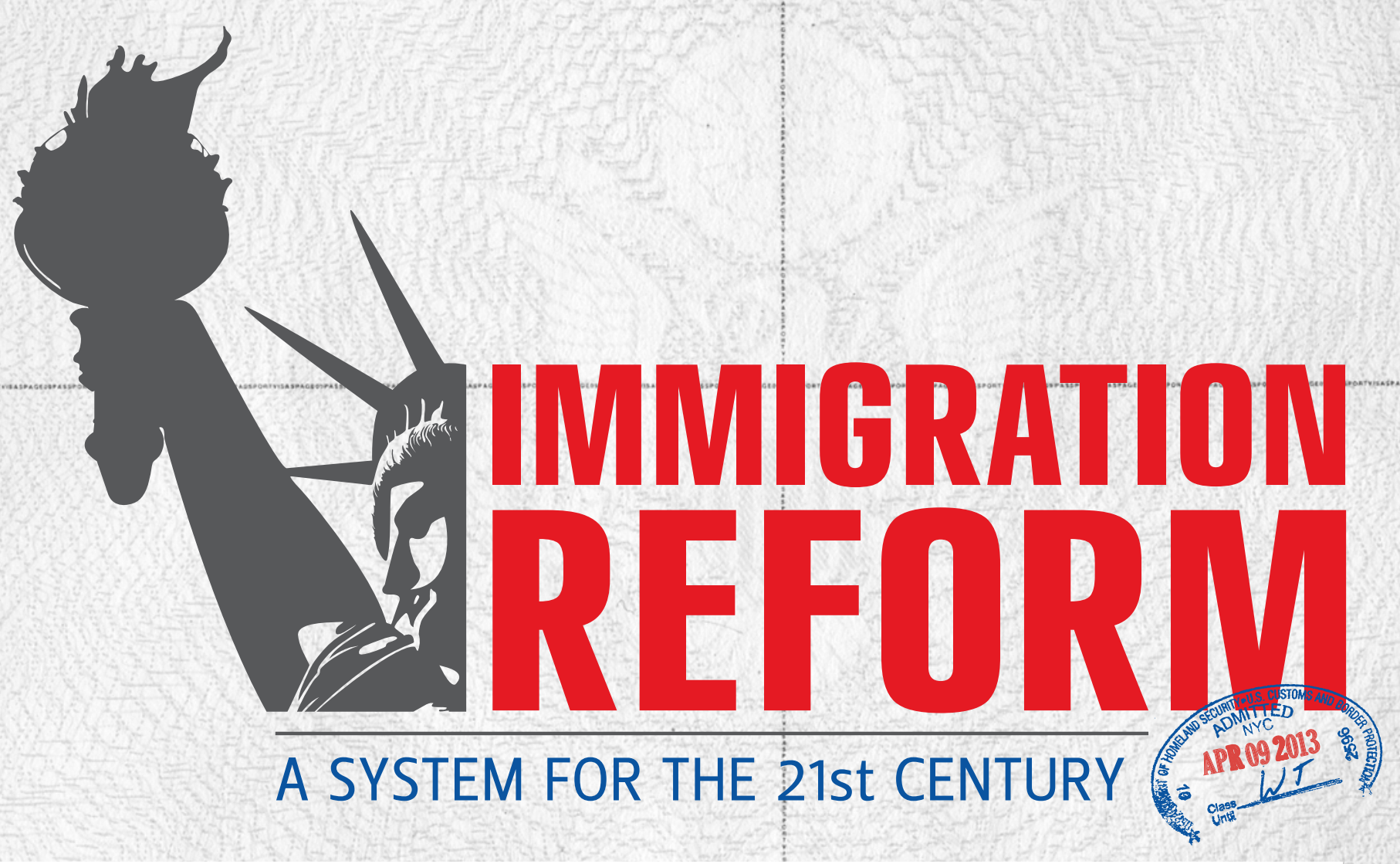

Immigrants in the U.S. Labor Market

Pia M. Orrenius, Ph.D.

Madeline Zavodny, Ph.D. 


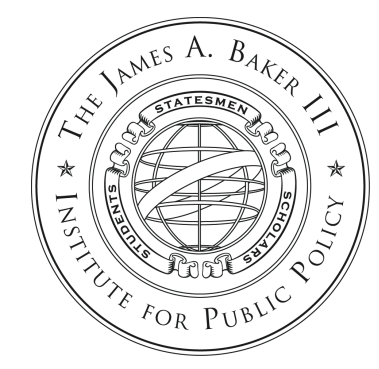

JAMES A. BAKER II I INSTITUTE FOR PUBLIC POLICY RICE UNIVERSITY

LATIN AmERICA INITIATIVE IMMIGRATION RESEARCH ProJECT WORKING PAPER

\title{
IMMIGRANTS IN THE U.S. LABOR MARKET
}

BY

\author{
Pia M. Orrenius, Ph.D. \\ LABOR ECONOMIST \\ Federal Reserve Bank of Dallas
}

AND

Madeline Zavodny, Ph.D.

Professor, DePARTMENT OF ECONOMICS

Agnes SCOTt College

APRIL 2013 
THESE PAPERS WERE WRITTEN bY A RESEARCHER (OR RESEARCHERS) WHO PARTICIPATED IN A BAKER INSTITUTE RESEARCH PROJECT. WHEREVER FEASIBLE, THESE PAPERS ARE REVIEWED bY OUTSIDE EXPERTS beFORE THEY ARE RELEASED. HOWEVER, THE RESEARCH AND VIEWS EXPRESSED IN THESE PAPERS ARE THOSE OF THE INDIVIDUAL RESEARCHER(S), AND DO NOT NECESSARILY REPRESENT THE VIEWS OF THE JAMES A. BAKER II I INSTITUTE FOR PUBLIC POLICY.

(c) 2013 By the James A. BAker I I I Institute for Public Policy of Rice University

THIS MATERIAL MAY BE QUOTED OR REPRODUCED WITHOUT PRIOR PERMISSION, PROVIDED APPROPRIATE CREDITIS GIVEN TO THE AUTHOR AND THE JAMES A. BAKER I I I NSTITUTE FOR PUBLIC POLICY. 


\begin{abstract}
Immigrants supply skills that are in relatively short supply in the U.S. labor market and account for almost half of labor force growth since the mid-1990s. Migrant inflows have been concentrated at the low and high ends of the skill distribution. Large-scale unauthorized immigration has fueled growth of the low-skill labor force, which has had modest adverse fiscal and labor market effects on taxpayers and U.S.-born workers. High-skilled immigration has been beneficial in most every way, fueling innovation and spurring entrepreneurship in the high tech sector. Highly skilled immigrants have had a positive fiscal impact, contributing more in tax payments than they use in public services. Immigration reform appears to be on the horizon, and policies such as a legalization initiative, a guest-worker program and more permanent visas for high-skilled workers would likely be an improvement over the status quo.
\end{abstract}

\title{
Introduction $^{1}$
}

The United States is the world's top destination for migrants. It is home to 19 percent of the world's migrants and between 40 and 50 percent of the world's unauthorized migrants. ${ }^{2}$ No other nation takes in as many immigrants. On the benefits side, immigration boosts the U.S. economy, enhances productivity, spurs innovation, helps consumers by keeping prices low, and enriches U.S. society and culture. On the costs side, there are at least two important caveats to consider. Immigrants to the United States are disproportionately low-skilled and, hence, low-wage. Lowwage immigrant households have an adverse fiscal impact, receiving more in public services than they pay in taxes, on average. Second, the economic gains from immigration are not distributed equally among natives. Competing low-skilled workers, for example, may suffer wage losses, and poor households will not benefit as much as rich ones from lower prices for immigrant-produced goods and services since they consume less of those products.

The positive economic impact is greatest for high-skilled and employment-based migration, particularly of science, technology, engineering, and math (STEM) workers, who can directly

\footnotetext{
${ }^{1}$ The views expressed are those of the author and do not reflect those of the Federal Reserve Bank of Dallas or the Federal Reserve System.

2 The United Nations estimates the world migrant stock was 214 million in 2010. See http://esa.un.org/migration/ (accessed February 15, 2013). The ILO estimates there are 20 to 30 million unauthorized migrants worldwide.
} 
influence innovation and, hence, productivity growth. However, U.S. policy allocates only a small fraction of permanent resident visas to employment-based immigrants, who are overwhelmingly high-skilled, reserving most so-called "green cards" for family and humanitarian cases - people who frequently have much less education than employment-based immigrants. In other words, quotas restrict the most economically-beneficial immigration by awarding permanent residence primarily on the basis of family ties. ${ }^{3}$

U.S. immigration policy has turned a blind eye to unauthorized immigration and the market forces that attract it, which has resulted in an undocumented immigrant population that now numbers over 11 million people. ${ }^{4}$ In recent years, several states have passed anti-immigrant legislation, adversely affecting an already vulnerable group. The large number of unauthorized immigrants and the shortage of high-skilled visas, along with a host of other issues, have prompted calls for comprehensive immigration reform. With the 2012 presidential election over, the White House and Congress appear ready to take action.

This paper proceeds by first discussing recent trends in immigration in the context of U.S. labor demand, including the volume of immigrant workers and their education, occupation, and geographic distribution. We then discuss the effects of immigration on economic output (gross domestic product, or GDP) and the rate of economic growth. Labor market and fiscal effects are then discussed, with particular attention to the impacts by educational attainment. Last, the implications of the economic analysis are explored in the context of current and proposed immigration policy.

\footnotetext{
${ }^{3}$ This article does not speak directly to the benefits or costs of humanitarian immigration; the volume of refugees to accept should be determined primarily on humanitarian and geopolitical considerations rather than economic principles.

${ }^{4}$ J.S. Passel and D’Vera Cohn, “Unauthorized Immigrants: 11.1 million in 2011,” Pew Hispanic Center:Washington, D.C., 2012.
} 


\section{Trends in Immigration}

The foreign-born population rose from 25 million in 1996 to just over 40 million in 2011, representing 13 percent of the total population. ${ }^{5}$ This share is on par with many Western European countries although not as high as Canada, at 20 percent, or Australia, at 27 percent. The share of workers who are foreign born is higher than the population share because immigrants are more likely to be of working age. Of the 40 million immigrants in the United States, 25 million of them work, making up 16 percent of the labor force (Figure 1). Even more significantly, between 1996 and 2011, immigrants accounted for 51 percent of labor force growth. As the U.S. population ages and the labor force participation rate among the U.S.-born continues to fall, the role of immigrants in labor force growth will likely remain substantial.

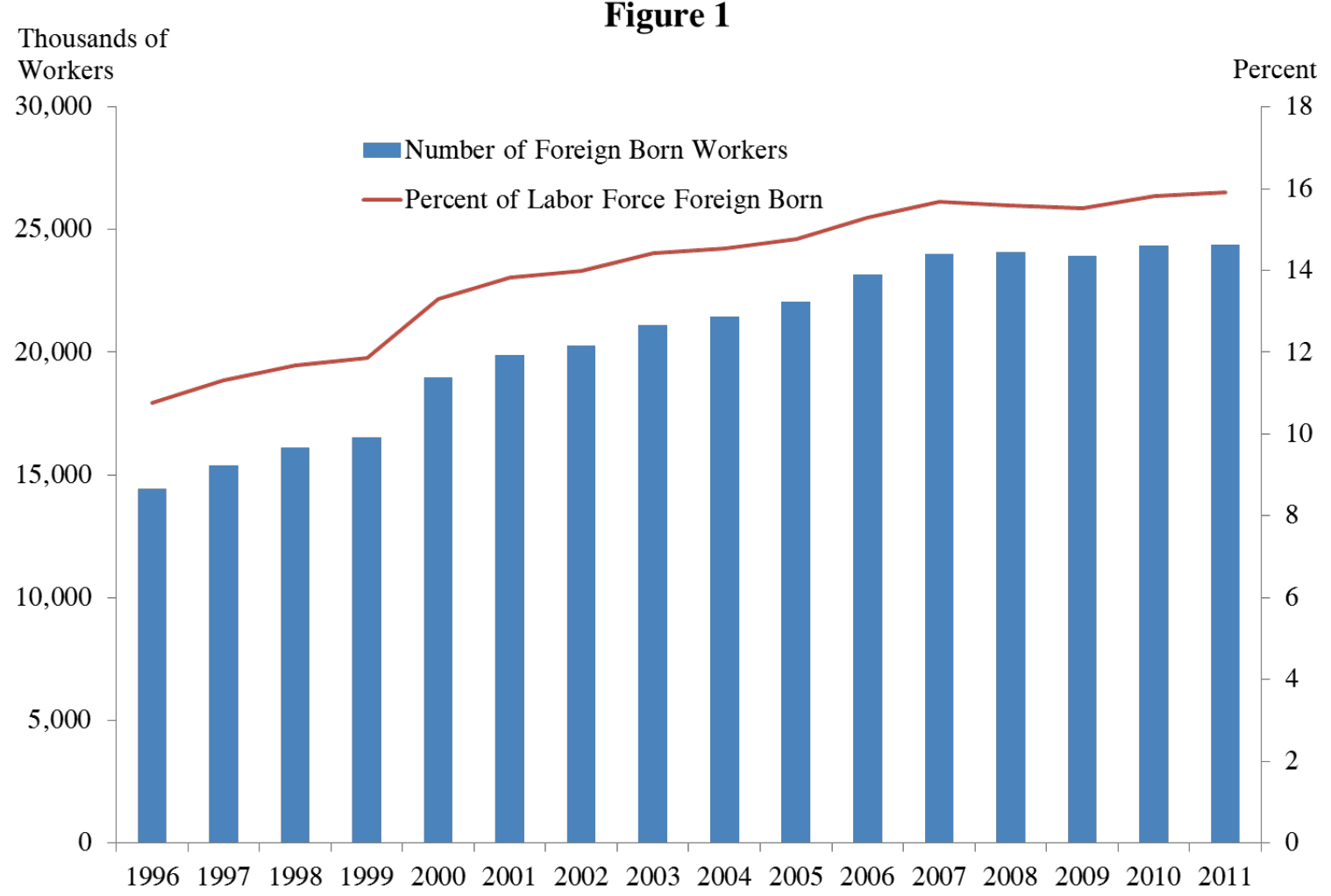

Source: Bureau of Labor Statistics

\footnotetext{
${ }^{5}$ We use the terms "immigrant" and "foreign-born" interchangeably in this article to refer to all individuals residing in the United States who were born abroad to non-U.S. parents. Immigrants thus include legal and illegal, temporary, and permanent residents.
} 


\section{Countries of Origin}

U.S. immigration is the outcome of push and pull factors. Push factors represent poor conditions in the home country, whether they are low wages, corruption, violence, or a lack of jobs. Pull factors include economic growth in the United States and the inability or unwillingness of domestic labor force to respond quickly to increases in labor demand. Ties to family and friends already here are an important pull factor for workers and nonworkers alike.

Costs also play into migration decisions. Distance is a good catchall measure of migration costs. Geographic proximity typically means the historic, economic, social, cultural, and linguistic ties are stronger between two nations. In the U.S. case, geographic proximity, along with strong push and pull factors, have ensured large and persistent migration flows from Mexico. In 2011, 12 million U.S. immigrants were from Mexico, constituting 29 percent of the total. Mexico is followed by China with 6 percent of U.S. immigrants and India with 5 percent. The Philippines, El Salvador, and Vietnam round out the top six sending countries, which together account for half of all immigrants.

Immigration policy is the other important cost factor. Immigration policy plays a critical role in determining who comes and how. Quotas that restrict the number of permanent resident visas available in various categories and restrictions on temporary foreign worker visas affect how hard it is to enter legally. Border and interior enforcement affect how hard it is to enter or remain in the country illegally.

\section{Education and Occupation Distribution}

For the last three decades or so, employer demand for foreign workers has been particularly strong at the low and high ends of the skill distribution. Top jobs for low-skilled immigrants include occupations such as housekeepers and maids, cooks, janitors, farm workers, construction laborers, gardeners, and groundskeepers. Top occupations among high-skilled immigrants include managers and administrators, computer software developers, registered nurses, subject instructors, accountants and auditors, computer systems analysts, and physicians. At both ends of the skill distribution, immigrants have flowed into occupations and industries that have either 
grown quickly, outstripping native supply, or that natives have, over time, either exited or eschewed.

Immigration policy has helped shape immigrants' educational composition. Immigration policy has actively constrained immigration by highly educated workers, while facilitating family-based immigration, a group with considerably lower levels of education. The lack of effective border and interior enforcement has also resulted in large flows of unauthorized migrants with relatively little education compared with U.S. natives. As a result, nearly one-third of U.S. immigrants lack a high school diploma or equivalent (Figure 2). About 40 percent have a high school diploma but no college degree, and 27 percent have a college degree or higher. The foreign born are concentrated at the bottom and top of the education distribution while natives are massed in the middle.

\section{Figure 2}

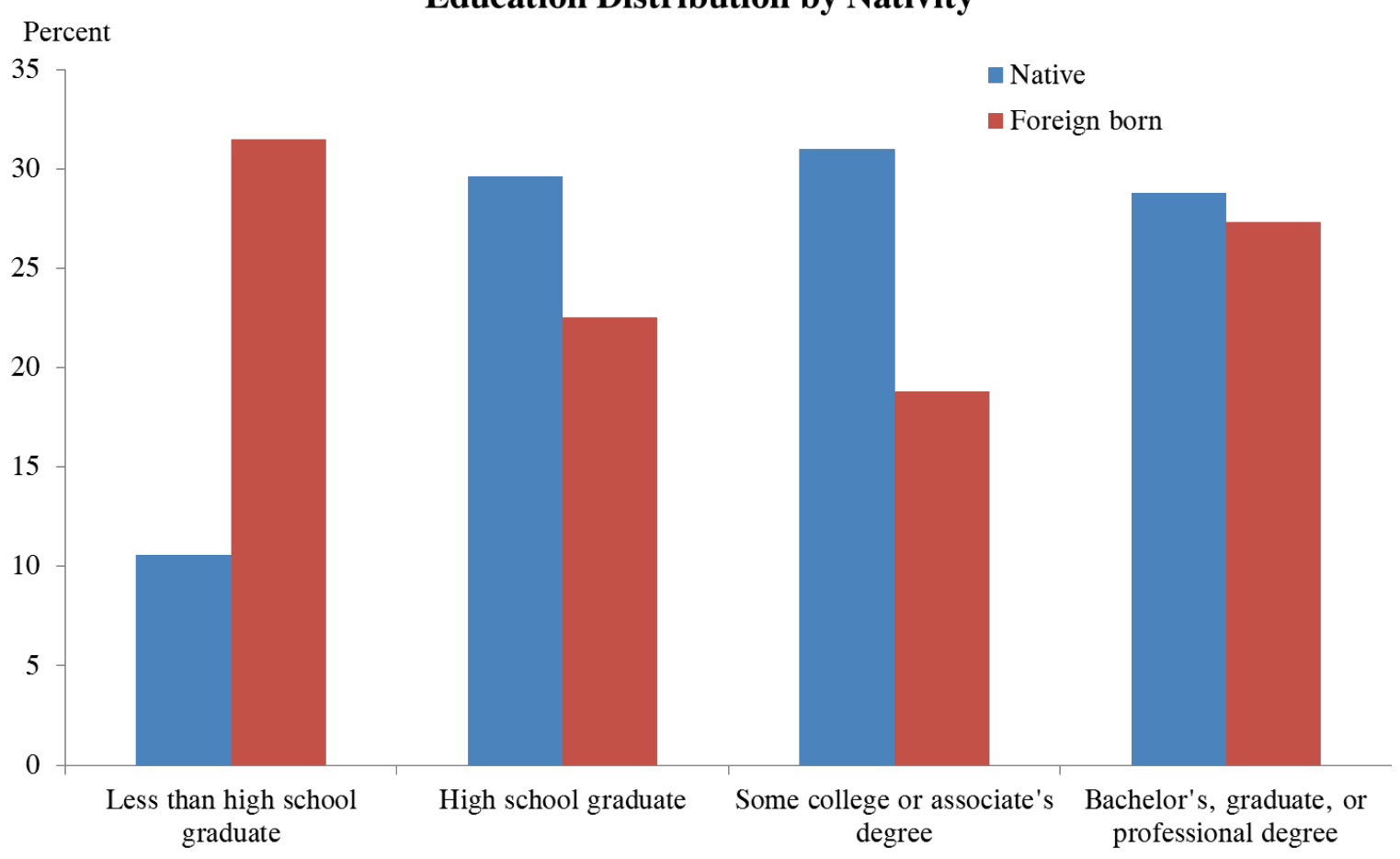

Source: 2011 American Community Survey 


\section{Geographic Distribution}

The geographic distribution of immigrants has traditionally been a function of prior migration. New migrants tend to choose destinations where they have strong migrant networks, and states with large settled immigrant populations are sometimes called "gateway states." The map below (Figure 3) illustrates the uneven distribution of foreign workers; states with a higher portion of the nation's foreign labor supply than their portion of the native labor supply are shaded more darkly and include California, Nevada, New York, and New Jersey at the high end (where the foreign-to-native worker ratios exceed 1.7) and Texas, Florida, Illinois, Massachusetts, and Maryland on the lower end of the high scale (with ratios between 1 and 1.7). States with relatively low shares of foreign workers, shaded the lightest, include West Virginia, Montana, North and South Dakota, Mississippi, and Maine, among others.

Figure 3

\section{Foreign Born Worker Concentration by State}

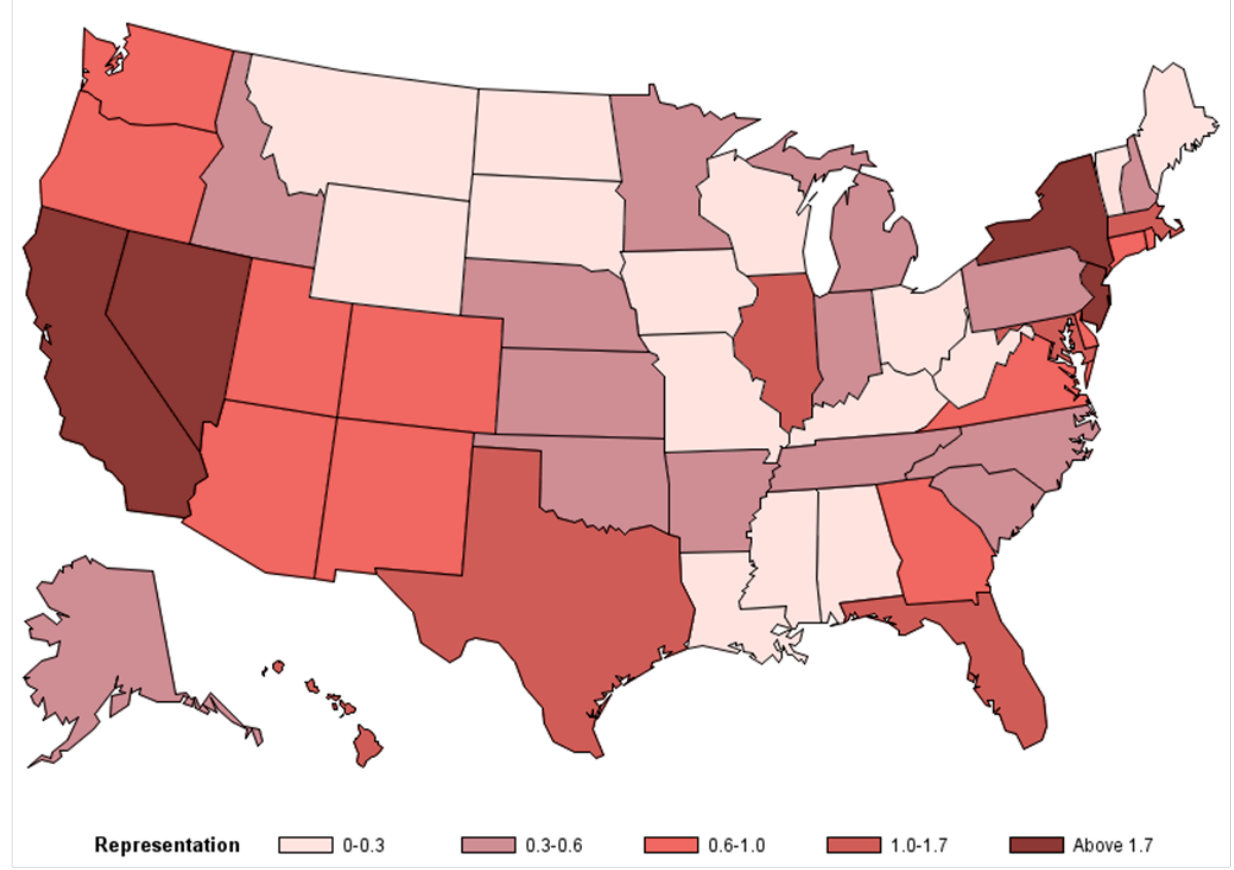

NOTE: Data in AK, ME, MT, SD, VT, WV are from the 2009-2011 3-year American Community Survey estimates, data in ND and WY are from the 2009 American Community Survey, and data in the remaining states are from the 2011 American Community Survey.

Arriving in a gateway state does not imply that immigrants will stay there. In fact, following arrival, migrants respond to economic incentives and move for better employment and wage opportunities much like other groups (Cadena 2011; Card and Lewis 2007). The great 1990s 
dispersion of U.S. immigrants away from gateway states, such as California and Texas, is evidence of the responsiveness of foreign workers to economic incentives. In the Mexican case, Bean et al. (2007) note that three of the five traditional Mexican-receiving U.S. states experienced net out-migration of Mexicans in the 1990s. Mexicans and other immigrants moved to states in the South and mountain regions of the country, which were experiencing faster economic growth at that time. By 2000, one-quarter of Mexican immigrants resided outside the five traditional gateway states, up from only one-tenth a decade earlier. ${ }^{6}$

\section{Effect on Economic Activity}

\section{Immigration and $G D P$}

Immigrants help power and grease the economy's engines. First, immigration increases the labor force, enlarging the economy. Although they make up only 16 percent of the U.S. workforce, these immigrants account for a much larger share of its growth. Just over half of the increase in the U.S. labor force between 1996 and 2010 was the result of immigration-legal and illegal. The role of native-born workers in workforce growth is diminishing due to several factors, including declining labor force participation rates. As the native-born population ages over the next 20 years, the foreign-born contribution to labor force growth is expected to stay high or even increase. This will help offset the 80 million baby boomers retiring from the U.S. workforce over the next two decades. ${ }^{7}$

When immigrants flow into the labor force, it is not just a question of adding more workers. As long as immigrants differ from natives - which they do in varying degrees-specialization occurs. Native and immigrant workers sort into the jobs and tasks that they do relatively well. For example, one recent study shows that natives have a comparative advantage in communication-intensive work, while immigrants have a comparative advantage in manual labor

\footnotetext{
${ }^{6}$ Mark A. Leach and Frank. D. Bean, "The Structure and Dynamics of Mexican Migration to New Destinations in the United States," in New Faces in New Places (New York: Russell Sage Foundation, 2008).

${ }^{7}$ Social Security Administration, "Annual Performance Plan for FY 2012 and Revised Final Performance Plan for FY 2011,” 2012, http://www.socialsecurity.gov/performance/2012/APP\%202012\%20508\%20PDF.pdf.
} 
jobs. ${ }^{8}$ Specialization increases efficiency, which allows more output to be produced with fewer resources. This boosts labor market productivity, raising economic output, or GDP.

Although the bulk of GDP gains go to the immigrants in the form of labor earnings, the nativeborn population benefits from the immigrant influx through lower prices and the specialization in production described above. The effect of immigration on the GDP accruing to natives has been termed the "immigration surplus" (Borjas 1995). Estimates suggest the gain to natives' incomes from immigration is about $\$ 38-\$ 75$ billion per year, which is not insignificant even though it represents less than 0.5 percent of the $\$ 16$ trillion U.S. economy. Consumers benefit from lower relative prices for goods and services, and investors, business owners, and landowners from higher returns on capital and land. In cases where immigrants and natives are complements, lower prices can have far-reaching effects. For example, research shows the immigrationinduced decrease in the cost of child care and housekeeping has significantly increased the labor supply of highly educated native women (Cortés and Tessada 2011).

\section{Immigration Surplus: Education and Spillovers}

The immigration surplus depends on, among other things, the relative skill levels of migrants, host country institutions, and spillover effects. If the migrant skill composition is unlike that of natives, then immigrants are complementary to most domestic workers, which means immigrants and natives mutually supply what the other lacks. In this case, the immigration surplus is larger than it would be if migrants and natives were close substitutes, which is when one can perform the work of the other (Borjas 1995). If capital is taken into account, the benefits of high-skilled immigration in particular are larger. Capital represents the economy's stock of financial and physical assets, including technology. Research suggests skilled migrants are complementary to capital, implying the immigration surplus is larger when high-skilled rather than low-skilled immigration occurs in a capital-intensive economy, such as the United States. There is an added benefit if high-skilled immigrants are more likely to bring capital with them when they migrate, such as their own savings which can then be used for investment.

\footnotetext{
${ }^{8}$ Giovanni Peri and Chad Sparber, "Task Specialization, Immigration, and Wages," American Economic Journal: Applied Economics 1 (2009):135-169.
} 
A look at where immigrants are in the educational distribution of U.S. workers reveals that immigrant flows have been largely complementary to natives, occurring at the high and low ends of the education distribution where there are relatively few U.S.-born workers. That said, newcomers are most overrepresented at the lowest education level, among workers who lack a high school degree (Figure 4). Half of workers with less than a high school diploma are foreignborn. ${ }^{9}$ Conversely, 29 percent of workers with doctoral degrees are foreign-born. Overall, foreign-born workers account for about 18 percent of all U.S. workers age 25 and older (see dashed line in Figure 4).

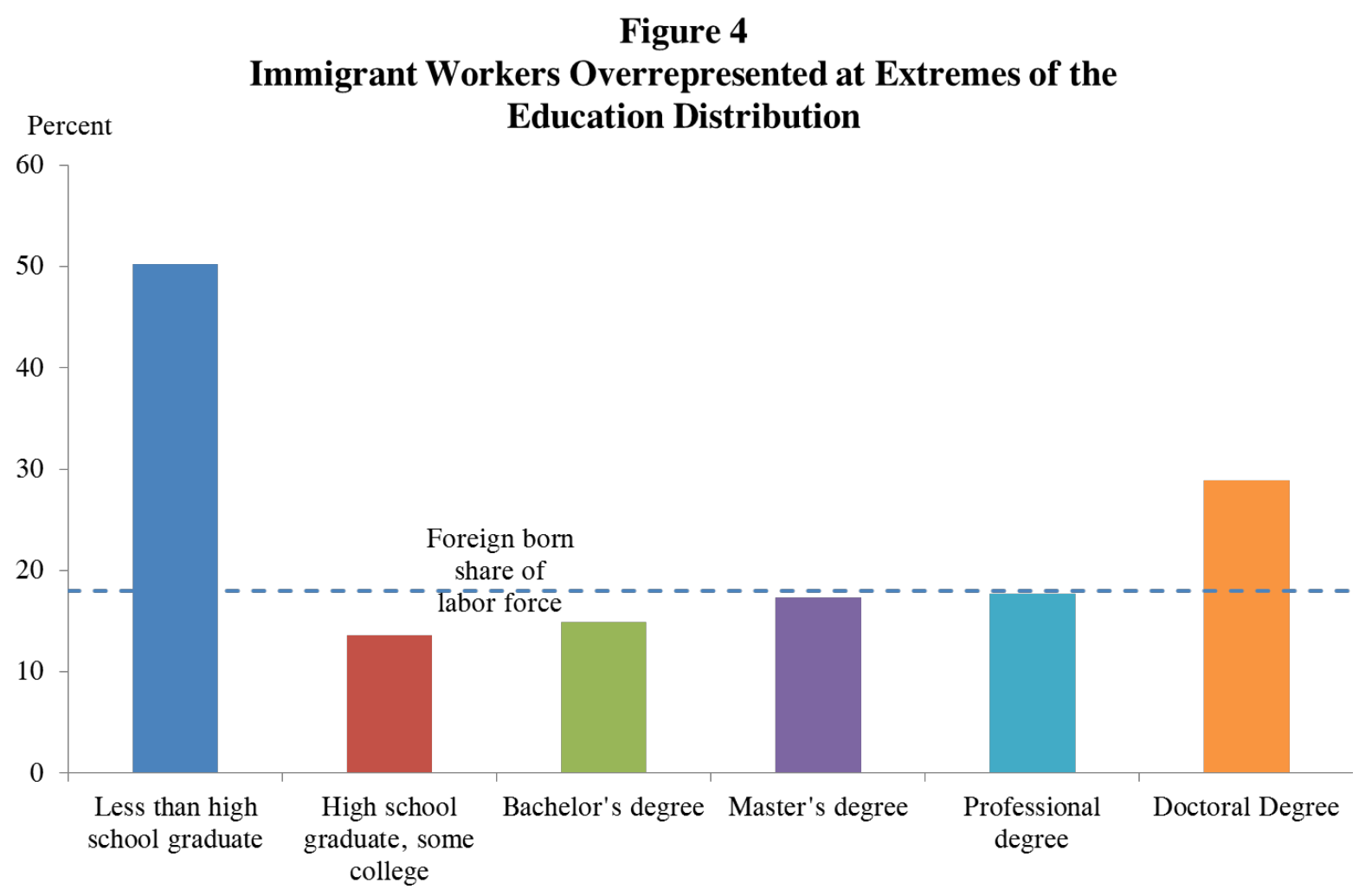

Note: Percent of foreign workers age 25 and over in the U.S. labor force by education. Source: 2011 American Community Survey

If immigration has external or spillover effects on the U.S. economy, the immigration surplus may be smaller or larger than the estimates noted above. Congestion and pollution costs

\footnotetext{
${ }^{9} 25.5$ percent of foreign-born workers ages 25 and over lack a high school diploma compared with 5.3 percent of native-born workers.
} 
associated with population growth can reduce the immigration surplus while the new arrivals' innovation and business creation, as discussed below, can increase it.

\section{Migrant mobility}

Immigrants' relatively greater mobility than natives - the willingness to relocate to where economic opportunity exists - contributes to the U.S. economy (Borjas 2001). For example, the Hispanic population in Louisiana jumped nearly 20 percent following Hurricane Katrina in 2005, as migrant workers converged upon the state to assist in cleanup and reconstruction. Most regional disparities, however, emerge more slowly as some industries decline and workers are reluctant to relocate, driving wages down and unemployment rates up in already distressed areas. Moving to growing areas helps reverse this process and speeds wage convergence. Immigrants are more likely to do this than natives, particularly among the less educated. Immigrants also alleviate shortages and bottlenecks that can thwart economic growth in expanding areas. The economy runs more efficiently as a result. The gains accruing to natives from this convergence are around $\$ 8$ billion to $\$ 16$ billion per year. ${ }^{10}$

\section{Immigration and Economic Growth}

The static effects of immigration on the macro economy from specialization and greater efficiency are one-time gains that boost output but do not change the long-run growth rate. In the longer term, increases in income per capita come from productivity growth, a result of technological progress. Technological progress, in turn, depends on innovation, which is closely related to research and development activities.

Recent research provides ample empirical evidence that immigrants with advanced skills play an important role in innovation (Hunt and Gauthier-Loiselle 2010), (Kerr and Lincoln 2010), (Hunt 2011), (Chellaraj, Maskus, and Mattoo 2008). Highly educated immigrants receive patents at more than twice the rate of highly educated natives. The difference has been linked to immigrants' overrepresentation in STEM (science, technology, engineering, and math) fields and to the growing number of immigrants entering on employment-based and student visas. There is also evidence of positive spillovers on natives, meaning that immigrants not only raise

\footnotetext{
${ }^{10}$ Based on Borjas, 2001.
} 
innovation directly but also boost overall patent activity, perhaps by attracting additional resources and boosting specialization.

Innovation is also closely related to entrepreneurship, particularly in the high-tech sector. Immigrants founded 25 percent of U.S. high-tech startups between 1995 and 2005 (Wadha et al 2007). In the overall economy, immigrants also have much higher rates of business creation than natives. Immigrants are nearly 30 percent more likely to start a business than natives (Fairlie 2008). This is surprising given that immigrants typically have less wealth, worse English skills, and limited institutional knowledge and less access to bank credit than natives. However, despite a greater proclivity to become entrepreneurs, immigrant self-employment rates are not too different from those of natives. The self-employment rate among immigrants was 11 percent in 2010 compared with 9 percent among natives (Orrenius and Zavodny 2011).

Figure 5 shows the extent to which immigrants are overrepresented in STEM and health care occupations. Immigrants make up 16 percent of the college-educated labor force as a whole. However, they are 48 percent of medical scientists and 39 percent of computer programmers. Immigrants also have an outsized presence in medicine, engineering, higher education, accounting and auditing, nursing, and architecture. 


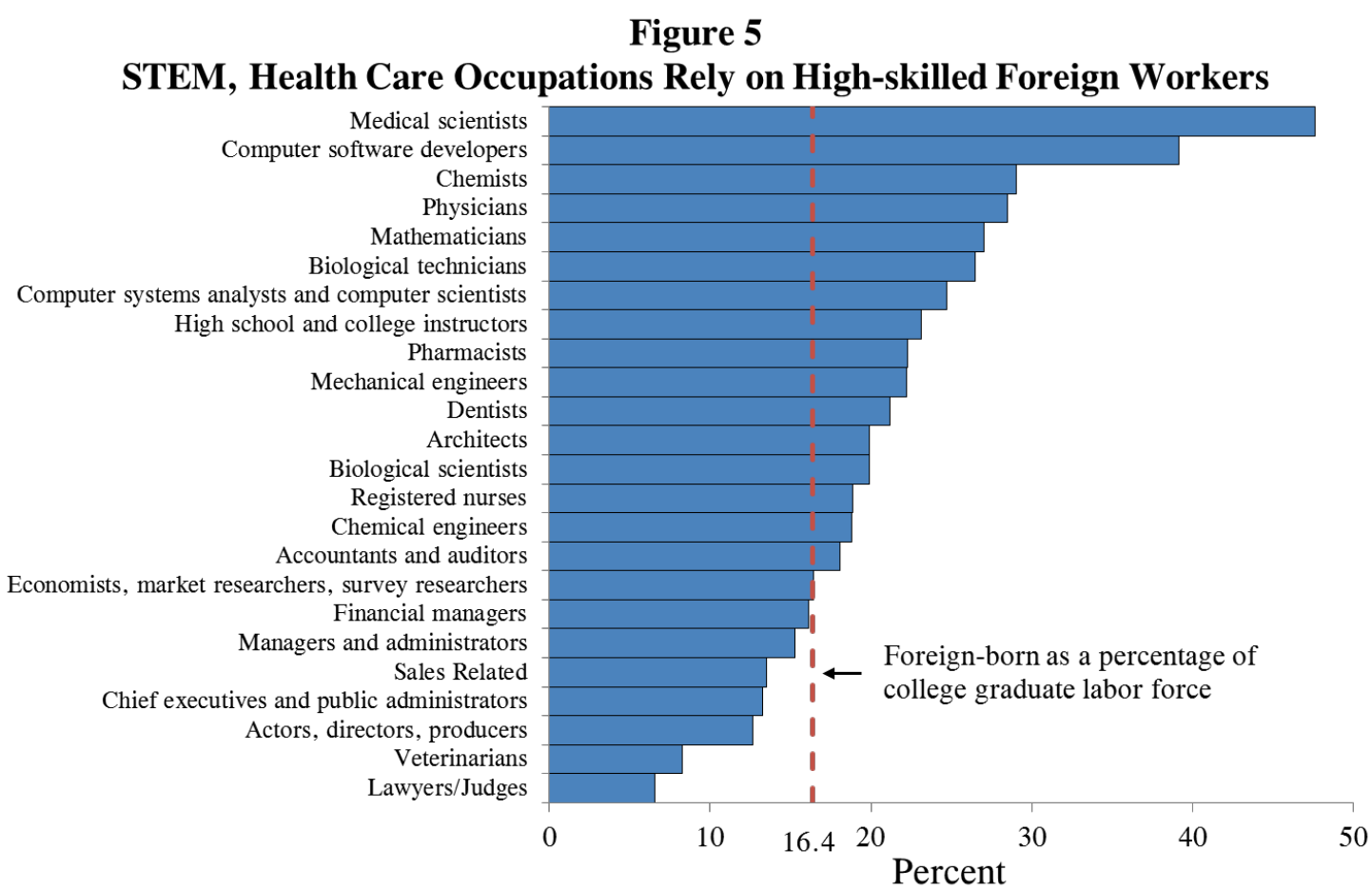

Note: Percent of workers age 25 and over, with bachelor's degree or higher who are foreign born for selected occupations.

Source: 2011 American Community Survey

\section{Labor Market Effects}

Many factors influence how immigration affects labor market outcomes. A simple model of supply and demand predicts that immigration increases the number of workers, pushing the labor supply curve out, which reduces wages. The magnitude of the effect on natives depends on the size of the immigrant inflows, how responsive labor demand is to changes in the number of workers, and how substitutable immigrants are for native workers. Some natives benefit from immigration, whereas others likely incur losses. Natives whose skills are complementary to those of immigrants are most likely to gain from immigration, and natives with substitutable skills are most likely to lose (Ottaviano and Peri 2012), (Orrenius and Zavodny 2007). The brunt of the negative labor market impact falls on earlier immigrants, not natives, because they are most similar to new immigrants and hence compete most closely with them. 
The preponderance of empirical evidence indicates that the adverse impact of immigration on natives' wages is considerably smaller than might be expected given the magnitude of immigration to the United States, particularly of low-skilled workers. For example, Card (2001) concludes that immigrant inflows reduced wages and employment rates of low-skilled natives in traditional gateway cities like Miami and Los Angeles by 1-3 percentage points during the 1980s. Ottaviano and Peri (2012) find that immigration inflows during 1990-2006 reduced wages among natives without a high school diploma by about 1 percent in the short run and actually increased their wages slightly in the long run. Some other research indicates more negative effects, such as Borjas's (2003) conclusion that immigration inflows during 1980 to 2000 reduced wages among natives without a high school diploma by almost 9 percent. But even the most adverse estimates suggest that other factors, not immigration, played a dominant role in the long-term decline in wages for less-educated natives. ${ }^{11}$

Why doesn't immigration have a more negative effect on natives? If immigrant workers are complementary to natives, then efficiency gains from immigration may push up productivity and thereby raise natives' earnings (Peri 2012). Industry or occupation mix may change in response to immigration as well. Research suggests that when the cost of labor falls, firms employ production processes that use more labor than they would have otherwise (Card and Lewis 2007). The decline in the cost of labor also raises the relative return to capital, so immigration may also spur investment and inflows of capital. Another reason is that immigrants tend to move to booming areas that otherwise might experience labor shortages. Natives and other immigrants may also move in response to immigration, making adverse wage effects difficult to measure. And immigrants are themselves consumers and create jobs via their own effect on aggregate demand. Last but not least, certain immigrants also create jobs via their entrepreneurial activities and innovation, as discussed above.

\footnotetext{
${ }^{11}$ Labor market institutions, particularly the fall in the real (inflation-adjusted) minimum wage, played a larger role than immigration (Card and DiNardo 2002).
} 


\section{Fiscal Effects}

Apart from immigration's direct impacts on the economy and growth, it has a fiscal impact—-the difference between what immigrant families pay in taxes and consume in government-provided benefits. High-skilled immigrants, generally well educated with substantial incomes, pay more in taxes than they consume in publicly-provided services (Smith and Edmonston 1997). By comparison, low-skilled immigrants are a net fiscal drain because of their low wages, large families, and lack of employer-provided health insurance coverage. In 2010, about 31 percent of immigrant-headed U.S. households participated in a major means-tested public assistance program, compared with 19 percent of native-headed households (Orrenius and Zavodny 2011). It is important to note that higher welfare participation among immigrants in the United States is not related to lower employment among low-education, foreign-born household heads (which is often the case in other advanced economies). In the U.S., low-education immigrants actually have much higher labor force participation rates than similar natives. Rather, the difference is due to greater immigrant participation in public health insurance programs, such as Medicaid and the Children's Health Insurance Program (CHIP).

It is also important to note that, in the very long run-across generations- the negative fiscal impact of low-skilled immigrants dissipates. This happens through the assimilation of their children, grandchildren, and later generations, who eventually reach average or above-average education and income levels and "pay back" the costs imposed by their ancestors. Rapid economic integration of the second and third generations pays large dividends for the host country.

With regard to unauthorized immigrants, most attempts to calculate their net fiscal impact conclude that they also pay less in taxes than they receive in services, on average (Congressional Budget Office 2007). Like low-education legal immigrants or low-education natives, they receive more in government benefits than they pay in taxes, on average. However, since they are not eligible for most welfare programs, illegal immigrants have a smaller adverse fiscal impact than low-wage legal immigrants. In both cases, the fiscal burden is particularly heavy for state and local governments, which bear a large share of costs for schools and health care. 


\section{Policy Implications}

The global reallocation of workers from low- to high-income countries yields very large benefits. Economic opportunity attracts immigrants who take advantage of it and enjoy a higher standard of living as a result. Meanwhile, immigration can boost the economic growth of host countries, which benefits natives. So why is immigration reform so controversial?

The problem with devising immigration policy arises from the fact that the gains from migration or from immigration reform, such as a legalization program, accrue largely to the migrants, with only a small share of gains falling to host country natives. Further, those gains are not distributed evenly, as some native workers are hurt by the migrant influx into the labor market, as noted above. Moreover, the gains for natives are either augmented or reduced by immigration's fiscal impact. For this reason, the calculations of immigration's net benefits for natives depend not only on the volume of immigration, but also on its composition. In this section, we briefly review current U.S. immigration policy and some of its problems. We then review possible reform measures and discuss their likely economic impact.

\section{Family Reunification Policy}

Since the 1965 amendments to the Immigration and Nationality Act, U.S. policy has been based on the principle of family reunification. Immediate relatives of U.S. citizens (spouses, parents, and unmarried children under age 21) are allowed in without numerical limit. Additional relatives, up to 480,000 per year, enter via four capped preference categories. First preference is for the unmarried adult children of U.S. citizens; second, spouses and children of legal permanent residents; third, married children of U.S. citizens; fourth, siblings of U.S. citizens. After five years on a green card, permanent residents can naturalize. Once citizens, they too can sponsor their foreign-born relatives. ${ }^{12}$

Additional capped green card categories include employment-based visas $(140,000)$ and diversity visas $(55,000)$ for immigrants who come from nations with low U.S. migration rates.

\footnotetext{
${ }^{12}$ The concern over chain migration likely spurred lawmakers to draft immigrant admission bars as part of the 1996 immigration reform (IIRIRA). The 3- and 10-year bars prevent unauthorized immigrants inside the U.S. from adjusting status without first spending several years in their home countries. The bars have therefore prevented thousands of immigrants who are otherwise eligible for permanent resident status from receiving their green cards.
} 
There is no explicit cap on the number of refugees or asylum-seekers who can receive permanent resident status, though refugee admissions are subject to annual limits set by the president.

Under this system, the U.S. annually issues about 1.1 million green cards. About 86 percent go to family members of U.S. citizens or permanent legal residents, people seeking humanitarian refuge, and diversity immigrants. The remaining 14 percent go to people who are immigrating for work reasons - but half of these are for workers' spouses and children, meaning a mere 7 percent of green cards go to so-called principal workers, most of whom are high-skilled. ${ }^{13}$ As can be seen in Table 1, no other major developed economy places such a low priority on permanent employment-based immigration.

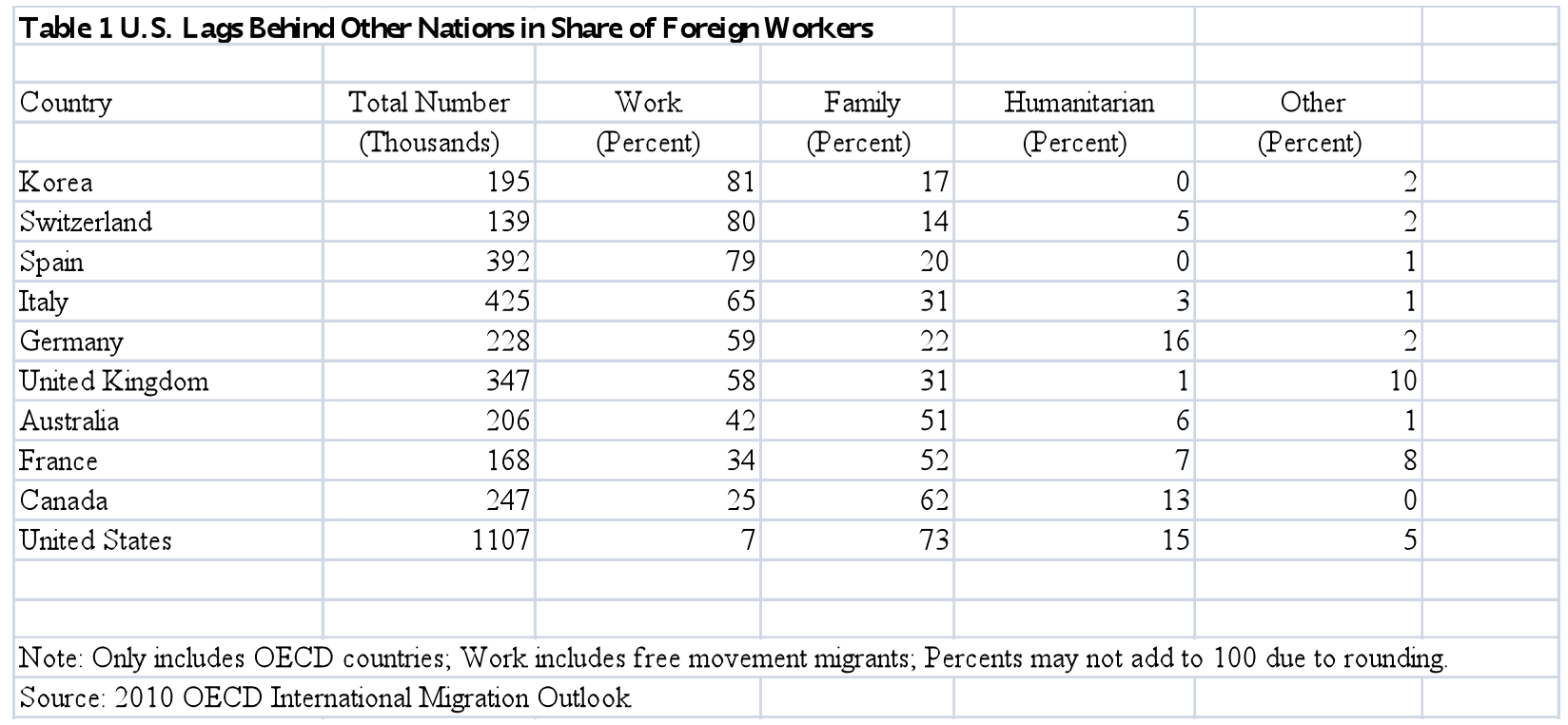

The U.S. has created several temporary visa programs in the past two decades to help compensate for the low number of hard-to-get employment-based green cards. Under the wellknown H-1B program, about 100,000 workers enter the country in a typical year, many of them skilled Indians going to work in the information technology sector. ${ }^{14}$ Another important temporary job-based measure is the Trade NAFTA (TN) visa, which admits an additional 70,000-plus professionals, mostly from Canada but a growing number from Mexico. The L1

\footnotetext{
${ }^{13}$ Calculations based on averages over the last five years as published in the Department of Homeland Security, Yearbook of Immigration Statistics. See also Jasso et al. (2000).

${ }^{14}$ The figure is the average during the 2006-2011 period and is based on U.S. CIS data on H-1B petitions approved for initial employment.
} 
program allows multinational corporations' intracompany transferees (about 75,000 annually), and the $\mathrm{O} 1$ program provides visas for a small number of workers of "extraordinary ability."

As temporary visa usage grew in the 1990s and 2000s, quotas for employment-based green cards remained unchanged. The mismatch in the number of immigrants on temporary visas who wished to stay in the U.S. and the number of available permanent residence visas produced unprecedented green card queues. Nearly 1.1 million skilled workers, including family, were waiting for an employment-based green card in fiscal year 2006 (Jasso et al. 2010). Many more have likely given up and left the U.S. or never bothered applying. For those in the queue, green cards typically won't be available for years because of the strict numerical limits on employment-based permanent visas. There also are country of origin limits that restrict the number of immigrants from each country, making the queues for would-be migrants from populous nations such as India and China even longer.

U.S. immigration policy is even more restrictive with regard to low-skilled workers, with little opportunity for legal entry. There are two temporary visa programs designed for low-skilled workers, the H-2A (for farm workers) and H-2B (other seasonal workers) programs. Both are for employment stints of less than one year. In a typical year prior to the recession, these programs together would bring in 110,000 workers. Meanwhile, about four times as many workers would enter illegally (Cohn and Passel 2010).

The U.S. has more unauthorized immigrants than any other nation in the world, although illegal inflows tapered off significantly during the recent recession and housing bust. Still, an estimated 11 million unauthorized immigrants reside permanently in the U.S. (Passel and Cohn 2011). Many of the least-skilled workers depicted in Figure 1 entered the U.S. illegally at some point.

For decades, U.S. policy vis-à-vis unauthorized immigrants consisted of tightening border control. There was little to no interior enforcement (i.e., a crackdown on employers). Illegal immigration flourished under this system since, once inside, unauthorized immigrants lived fairly normal lives. This changed following the 9/11 terror attacks. Conditions for unauthorized immigrants deteriorated significantly as state and federal enforcement intensified. Worksite 
enforcement and other measures likely forced some undocumented migrants into selfemployment or the shadow economy, where wages are lower and fringe benefits are scarce. Others have left states that passed these laws, such as Arizona. Without comprehensive immigration reform, these tough policies are often counterproductive in that they exacerbate the negative fiscal impact of the low-wage immigrant population by reducing the taxes they pay and increasing their need for public assistance. Although unauthorized immigrants are not eligible for any welfare programs outside emergency medical care, their U.S.-born children are citizens and entitled to the full range of public assistance.

\section{Immigration reform}

The section above outlines shortcomings of current U.S. policy, including the large undocumented population, shortages of permanent resident visas, and restrictions on highskilled, employment-based immigration. In early 2013, after a seven-year hiatus, Congress and the White House released preliminary proposals for comprehensive immigration reforms that address the problems in current law. While the two proposals differ on some key details, they both include a legalization program for undocumented immigrants, additional green cards to reduce backlogs and admit more STEM workers, and increased interior and border enforcement. We have already discussed the economic benefits of high-skilled immigration. We turn now to the likely economic effects of an amnesty for unauthorized immigrants.

This time around, a legalization program will far exceed the magnitude of the only other such large-scale effort, the Immigration Reform and Control Act (IRCA) of 1986, which affected about 2 percent of the labor force. The undocumented today comprise about 8 million workers (over 5 percent of U.S. labor force), including 1.1 million in Texas and 1.9 million in California (Passel and Cohn 2011). The main economic effect of legalization would be higher earnings for those who legalize. Hispanic immigrants' wages increased 6 to 13 percent when they legalized their status after IRCA, with slightly larger effects among women than men. ${ }^{15}$ Legalization removes employers' risk of incurring penalties, which is often passed on to workers as lower wages, and allows immigrants to move to better, higher-paying jobs.

\footnotetext{
${ }^{15}$ See Catalina Amuedo-Dorantes, Cynthia Bansak, and Steven Raphael, "Gender Differences in the Labor Market: Impact of IRCA's Amnesty Provisions," The American Economic Review 97, No. 2 (May 2007): 412-416.
} 
The impact of a legalization program on native workers is likely small. Most unauthorized immigrant workers entered the U.S. labor market years ago, and affected employers and native workers have already adjusted to their presence. That said, labor market outcomes may worsen for natives and other immigrants if newly legalized immigrants compete more closely with them for jobs. However, compliance with tax withholding and labor regulations, from minimum wage laws to health and safety regulations, would likely increase, leveling the playing field by erasing some of illegal immigrant workers' current cost advantages.

Some benefits traditionally associated with unauthorized workers would dissipate with legalization. Employers, particularly in sectors of the economy that depend on a steady stream of such labor, currently benefit from the ready availability of people willing to hold any job, even undesirable ones that pay low wages. Consumers enjoy lower prices for goods and services. The immigrant wage gains after an amnesty are effectively a transfer to the newly legalized workers from employers and consumers. Another consideration is that legalization and, eventually, citizenship also could lead to additional illegal and legal immigration-which characterized the previous U.S. experience (Orrenius and Zavodny 2012). Reform proposals would likely include expanded border and interior enforcement, such as mandatory electronic verification of work authorization, to combat incentives to illegally migrate. A sizable and user-friendly temporary worker program for low-skilled workers would also be needed to reduce future unauthorized immigration.

Legalization would likely worsen the fiscal impact of low-skilled immigrants, although only in the medium to long term. In the short run, the fiscal impact is likely positive. Income and payroll tax revenues are likely to increase as some workers move onto the books instead of being paid under the table and pay back taxes, as is likely to be required by a new law. Of course, the effect may not be large since estimates suggest that over half of unauthorized immigrants already pay income and payroll taxes through withholding, filing tax returns, or both. ${ }^{16}$ On the spending side, most of the short-run impact would involve the U.S. citizen children of newly legalized

\footnotetext{
${ }^{16}$ See "The Impact of Unauthorized Immigrants on the Budgets of State and Local Governments," Congressional Budget Office, December 2007. Unauthorized workers use a variety of means to comply with tax laws. Some have been issued an Individual Taxpayer Identification Number (ITIN) or a Social Security number that is invalid for work, while others use fake numbers or numbers that belong to somebody else. Until the early 2000s, there were few consequences for workers who submitted false or fraudulent Social Security numbers.
} 
individuals. These minors are already eligible for means-tested benefits if family income is low enough, but may not be enrolled because of deportation fears.

There would be an added social benefit from greater family income and stability. Research indicates that Mexican-American young adults living in the United States complete more years of school, score higher on standardized tests, and learn better English if their parents are able to legalize their status. ${ }^{17}$

\section{Conclusion}

Robust labor demand, changes in native labor supply, permissive immigration policy, and a host of willing workers worldwide have combined to produce a large and persistent immigrant flow to the United States over the last three decades. Economic benefits accrue from both high- and lowskilled immigration. Both tend to complement the native workforce and bring needed skills and manual labor. Among employment-based immigrants, high-skilled workers, in particular, benefit the economy. In the U.S., high-skilled immigration alleviates shortages and bottlenecks in key science, health, and technology occupations and spurs innovation and investment in research and development. High-skilled workers also have a positive fiscal impact, contributing more in tax payments than they use in public services. Accordingly, immigration policy that prioritizes education and skills and brings in more high-skilled immigrants enhances immigration's benefits from the host-country's perspective.

There may be additional benefits to high-skilled immigration, although they are not yet welldocumented. Much of it involves industries that produce tradable goods or services, meaning companies can employ their workers in the U.S. or abroad. Immigration policy that promotes high-skilled immigration may slow outsourcing or offshoring of production. Such policies may also attract foreign and domestic investment, further spurring economic growth.

The U.S. has a lot to gain from immigration reform along the lines of what is currently under discussion in Washington, D.C. A carefully crafted legalization program can provide an even

\footnotetext{
${ }^{17}$ See Bean et al. 2006, Bean et al. 2011, and Pan, 2011.
} 
playing field for native and immigrant workers and boost tax revenue. More high-skilled and employment-based immigration will have far-reaching benefits in the form of more innovation and faster growth. Provisions such as mandatory electronic verification of work authorization, as in the president's plan, or a larger role for low-skilled employment-based immigration, as in the Senate plan, would prove instrumental in reducing unauthorized immigration in the future. 


\section{References}

Amuedo-Dorantes, Catalina, Cynthia Bansak, and Steven Raphael. 2007. "Gender Differences in the Labor Market: Impact of IRCA's Amnesty Provisions." The American Economic Review 97 (2): 412-416.

Bean, Frank D., Susan K. Brown, Mark A. Leach, and James Bachmeier. 2007. "Becoming U.S. Stakeholders: Legalization and Integration among Mexican Immigrants and Their Descendants.” Merage Foundation for the American Dream, Newport Beach, CA.

Bean, Frank D., Susan K. Brown, Mark A. Leach, James Bachmeier, Leo R. Chávez, Louis DeSipio, Ruben G. Rumbaut, James Lee, and Min Zhou. 2006. "How Pathways to Legal Status and Citizenship Relate to Economic Attainment among the Children of Mexican Immigrants." Center for Research on Immigration, Population, and Public Policy at the University of California, Irvine. Research Report to the Pew Center. Available at http://www.cri.uci.edu/pdf/PewReport 090506.pdf.

Bean, Frank D., Susan K. Brown, Mark A. Leach, James Bachmeier and John R. Hipp. 2011. "The Educational Legacy of Unauthorized Migration: Comparisons Across U.S.Immigrant Groups in How Parents' Status Affects Their Offspring." International Migration Review 45 (2): 348-385.

Borjas, George J. 1995. “The Economic Benefits from Immigration” Journal of Economic Perspectives 9 (2): 3-22.

Borjas, George J. 2001. “Does Immigration Grease the Wheels of the Labor Market?” Brookings Papers on Economic Activity 2001: 69-119.

Cadena, Brian C. 2011. "Native Competition and Low-Skilled Immigrant Inflows." University of Colorado Boulder.

Card, David and John E. DiNardo. 2002. "Skill-Biased Technological Change and Rising Wage Inequality: Some Problems and puzzles.” Journal of Labor Economics 20 (4): 733-783.

Card, David and Ethan Lewis. 2007. “The Diffusion of Mexican Immigrants During the 1990s: Explanations and Impacts." In Mexican Immigration to the United States, edited by George Borjas. National Bureau of Economic Research: Cambridge, MA.

Chellaraj, Gnanaraj, Keith E. Maskus, and Aaditya Mattoo. 2008. "The Contribution of International Graduate Students to U.S. Innovation.” Review of International Economics 16 (3): 444-62. 
Cohn, D’Vera and Jeffrey Passel. 2010. “U.S. Unauthorized Immigration Flows Are Down Sharply Since Mid-Decade.” Washington, D.C.: Pew Hispanic Center. http://www.pewhispanic.org/files/reports/126.pdf.

Congressional Budget Office 2007. "The Impact of Unauthorized Immigrants on the Budgets of State and Local Governments." http://www.cbo.gov/sites/default/files/cbofiles/ftpdocs/87xx/doc8711/12-6-immigration.pdf.

Cortés, Patricia and José Tessada. 2009. "Low-Skilled Immigration and the Labor Supply of Highly Educated Women.” Manuscript, University of Chicago Graduate School of Business.

Department of Homeland Security. "Yearbook of Immigration Statistics." Available at http://www.dhs.gov/yearbook-immigration-statistics.

Fairlie, Robert W. 2008. "Estimating the Contribution of Immigrant Business Owners to the U.S. Economy." Small Business Administration. Washington, D.C.: Government Printing Office.

Hunt, Jennifer. 2011. "Which Immigrants Are Most Innovative and Entrepreneurial? Distinctions by Entry Visa." Journal of Labor Economics 29 (3): 417-457.

Hunt, Jennifer, and Marjolaine Gauthier-Loiselle. 2010. "How Much Does Immigration Boost Innovation?" American Economic Journal: Macroeconomics 2 (2): 31-56.

Jasso, Guillermina, Douglas S. Massey, Mark R. Rosenzweig, and James P. Smith. 2000. "The New Immigrant Survey Pilot (NIS-P): Overview and New Findings about U.S. Legal Immigrants at Admission.” Demography 44 (2): 477-498.

Jasso, Guillermina, Vivek Wadhwa, Gary Gereffi, Ben Rissing, and Richard Freeman. 2010. "How Many Highly Skilled Foreign-Born are Waiting in Line for U.S. Legal Permanent Residence?" International Migration Review 37 (1): 127-138.

Kerr, William R., and William F. Lincoln. 2010. "The Supply Side of Innovation: H-1B Visa Reforms and U.S. Ethnic Invention." Journal of Labor Economics 28 (3): 473-508.

Leach, Mark A., and Frank D. Bean. 2008. "The Structure and Dynamics of Mexican Migration to New Destinations in the United States," in New Faces in New Places: The Changing Geography of American Immigration, edited by Douglas S. Massey. Russell Sage Foundation: New York.

Orrenius, Pia, and Madeline Zavodny. 2011. "From Brawn to Brains: How Immigration Works for America," in Federal Reserve Bank of Dallas 2010 Annual Report, Dallas. 
Orrenius, Pia, and Madeline Zavodny. 2007. "Does Immigration Affect Wages? A Look at Occupation-Level Evidence." Labour Economics.

Orrenius, Pia, and Madeline Zavodny. 2012. "The Economic Consequences of Amnesty for Unauthorized Immigrants." Cato Journal 32 (1): 85-106.

Ottaviano, Gianmarco I.P., and Giovanni Peri. 2012. "Rethinking the Effect of Immigration on Wages." Journal of the European Economic Association 10 (1): 152-197.

Pan, Ying. 2011. "Gains from Legality: Parents Immigration Status and Children's Scholastic Achievement.” Working Paper 2011-05. Department of Economics, Louisiana State University. http://bus.1su.edu/McMillin/Working_Papers/pap11_05.pdf.

Passel, J. S., and Cohn, D. 2011. "Unauthorized Immigrant Population: National and State Trends, 2010." Washington, D.C.: Pew Hispanic Center. http://pewhispanic.org/files/reports/133.pdf.

Passel, J. S., and D’Vera Cohn. 2012. "Unauthorized Immigrants: 11.1 Million in 2011." Washington, DC: Pew Hispanic Center. http://www.pewhispanic.org/2012/12/06/unauthorizedimmigrants-11-1-million-in-2011/.

Peri, Giovanni. 2012. "The Effect of Immigration on Productivity: Evidence from U.S. States." The Review of Economics and Statistics 94 (1): 348-358.

Peri, Giovanni, and Chad Sparber. 2009. "Task Specialization, Immigration, and Wages." American Economic Journal: Applied Economics 1:135-169.

Smith, James P., and Barry Edmonston. 1997. The New Americans: Economic, Demographic and Fiscal Effects of Immigration. Washington, D.C.: National Academies Press.

Social Security Administration. 2012. "Annual Performance Plan for FY 2012 and Revised Final Performance Plan for FY 2011.” Available at http://www.socialsecurity.gov/performance/2012/APP\%202012\%20508\%20PDF.pdf.

United Nations. 2009. "International Migrant Stock: The 2008 Revision." Available at http://esa.un.org/migration/.

Wadhwa, Vivek, Gary Gereffi, Ben Rissing, and AnnaLee Saxenian. 2007. “America's New Immigrant Entrepreneurs.” Unpublished report, Duke University. 